\title{
AKRUAL
}

Jurnal Akuntansi

http://fe.unesa.ac.id/ojs/index.php/akrl

\section{ANALISIS PENERAPAN PSAK - 102 MURABAHAH (STUDI KASUS PADA KSU BMT RAHMAT SYARIAH KEDIRI)}

\author{
Inggrid Eka Pratiwi \\ Mahasiswa Program Studi S1 Ekonomi Islam - Fakultas Ekonomi dan Bisnis - \\ Universitas Airlangga \\ Email: inggrid.pratiwi@gmail.com \\ Dina Fitrisia Septiarini \\ Departemen Ekonomi Syariah - Fakultas Ekonomi dan Bisnis - Universitas \\ Airlangga \\ Email: dina.fitrisia@gmail.com
}

Artikel diterima: 15 Juni 2014

Terakhir direvisi: 18 Agustus 2014

\begin{abstract}
The purpose of this research is to find out whether the accounting practices which include the recognition, measurement, presentation and disclosure of the murabaha transactions applied to the BMT Rahmat Syariah in accordance with PSAK 102 about accounting murabaha. The research method used is descriptive qualitative approach with this type of case study research. The Unit of analysis in this study is the accounting treatment of murabaha is applied to the BMT Rahmat Syariah. Analytical techniques used in this research is a domain analysis techniques. From the results of the research can be determined three related domains of contract i.e. the beginning of akkadian murabaha, during the process of installment and repayment. Research results can be concluded that BMT Rahmat Syariah in terms of recognition, measurement, presentation and disclosure of early contract deal not in accordance with PSAK 102. During the process of contract, in terms of the measurement of profit murabaha were in accordance with PSAK 102, but in terms of recognition, presentation, and disclosure is not in accordance with PSAK 102. Whereas in the recognition, measurement and disclosure of fines (ta'zir) is in compliance with PSAK 102 only served and which is not in accordance with PSAK 102. At the time of payment of the measurements were in accordance with PSAK 102, however, recognition, representation, and the disclosure is not in accordance with PSAK 102.
\end{abstract}

Keywords: Baitul Maal wa Tamwiil, Sharia Accounting, PSAK 102, Murabahah

\section{PENDAHULUAN}

Di Indonesia konsep ekonomi syariah mulai diterapkan sejak 1992 yang diawali dengan beroperasinya Bank Muamalat Indonesia (BMI) pada tanggal 1 Mei 1992 sebagai sebagai bank umum pertama yang beroperasi berdasarkan prinsip syariah, kemudian secara bergelombang muncul pula lembaga keuangan sejenis lainnya. Termasuk koperasi syariah atau lebih dikenal dengan Baitul Maal wa Tamwil (BMT). Koperasi Jasa Keuangan Syariah (KJKS) atau BMT adalah lembaga 
keuangan mikro berbadan hukum koperasi yang beroperasi berdasarkan prinsip syariah dengan tujuan menyediakan permodalan bagi masyarakat usaha mikro dan kecil.

Penyaluran dana dengan prinsip jual beli yang paling dominan adalah murabahah. Secara sederhana konsep murabahah dapat diartikan sebagai bentuk jual beli dengan adanya komisi atau suatu bentuk penjualan barang dengan harga awal ditambah keuntungan yang disepakati. Pembiayaan murabahah dapat dilakukan secara angsuran ataupun ditangguhkan dengan kesepakatan bersama. Dalam prakteknya sebagian besar kontrak murabahah yang dilakukan adalah dengan menggunakan sistem murabahah dengan pesanan. Kondisi ini dapat dimaklumi mengingat LKS bukanlah sebagai tempat yang menyediakan suatu barang atau komoditas tertentu yang dibutuhkan oleh seorang nasabah. Untuk mengadakan barang atau komoditas yang dibutuhkan nasabah, pihak LKS terlebih dahulu melakukan pemesanan kepada produsen terkait (pihak ketiga) yang kemudian disalurkan kepada nasabah yang memesannya. Oleh karena rumitnya skema pembiayaan murabahah maka dibutuhkan kerangka akuntansi yang menyeluruh yang dapat menghasilkan pengukuran akuntansi yang tepat dan sesuai sehingga dapat mengkomunikasikan informasi akuntansi secara tepat waktu dan kualitas yang dapat diandalkan.

Untuk itu Bank Indonesia (BI) yang dibantu sepenuhnya oleh Ikatan Akuntan Indonesia (IAI) menerbitkan Pernyataan Standar Akuntansi Keuangan (PSAK) tentang Perbankan Syariah. Pada tanggal 1 Mei 2002 secara resmi Dewan Standar Akuntansi Keuangan telah mengeluarkan PSAK No 59 yang terdiri dari a) Kerangka dasar penyusunan dan penyajian laporan keuangan bank syariah; b) Peryataan Standar Akuntansi Keuangan (PSAK) Akuntansi Keuangan Syariah.

Untuk seluruh transaksi murabahah LKS harus tunduk pada PSAK No 102. Sebagai pedoman dalam proses pengakuan, pengukuran, pengungkapan dan penyajian laporan keuangan. Diketahui bahwa pembiayaan dengan akad murabahah menjadi skema pembiayaan yang paling banyak disalurkan. Hal ini menunjukkan bahwa perkembangan bank syariah didominasi oleh produk jual beli atau murabahah.

Murabahah sebagai skema pembiayaan yang paling banyak diminati oleh nasabah ternyata masih terdapat kekurangan dalam hal proses akuntansi. Hal inilah yang mendorong peneliti untuk melakukan penelitian terhadap salah satu produk pembiayaan yang tidak menganut prinsip bunga/riba, melainkan menggunakan prinsip perolehan keuntungan atau margin yaitu pembiayaan murabahah. Dimana saat ini produk murabahah atau produk dengan sistem jual beli merupakan salah satu produk yang paling banyak dilaksanakan.

Rumusan masalah dalam penelitian ini adalah bagaimana penerapan akuntansi atas transaksi murabahah pada KSU BMT Rahmat Syariah Kediri, sedangkan tujuan dari penelitian ini adalah untuk mengetahui bagaimana perlakuan akuntansi atas transaksi murabahah di KSU BMT Rahmat Syariah Kediri.

\section{KAJIAN PUSTAKA \\ Baitul Mal wa Tamwil}

Baitul Mal wa Tamwil (BMT) adalah lembaga keuangan mikro yang beroperasi berdasarkan prinsip-prinsip syariah. BMT memiliki 2 fungsi utama yakni baitul mal dan baitul tamwiil. Ada beberapa pendapat tentang pengertian baitul mal 
wa tamwil. Soemitra (2009:451) berpendapat bahwa baitul mal (rumah harta) menerima titipan dana zakat, infaq dan sedekah serta mengoptimalkan distribusinya sesuai dengan peraturan dan amanahnya, sedangkan baitul tamwiil (rumah pengembangan harta) melakukan kegiatan pengembangan usaha-usaha produktif dan investasi dalam meningkatkan kualitas ekonomi pengusaha mikro dan kecil dengan antara lain mendorong kegiatan menabung dan menunjang pembiayaan kegiatan ekonomi.

Sudarsono (2008:103) berpendapat bahwa baitul mal lebih mengarah pada usaha-usaha pengumpulan dan penyaluran dana yang non-profit, seperti zakat, infaq, dan shodaqoh sedangkan baitul tamwiil sebagai usaha pengumpulan dan penyaluran dana komersial. Definisi BMT menurut operasional Pusat Inkubasi Bisnis Usaha Kecil (PINBUK, t.t:2) dalam peraturan dasar yakni "Baitul mal wa tamwil adalah suatu lembaga ekonomi rakyat kecil, yang berupaya mengembangkan usaha-usaha produktif dan investasi dalam meningkatkan kegiatan ekonomi pengusaha kecil bawah dan kecil berdasarkan prinsip syariah dan prinsip koperasi."

\section{Akuntansi Syariah}

Menurut Warren (2005:10) akuntansi dapat didefinisikan sebagai sistem informasi yang menghasilkan laporan kepada pihak-pihak yang berkepentingan mengenai aktivitas ekonomi dan kondisi perusahaan, sedangkan menurut AICPA (American Institute of Cerified Public Accountans) mendefinisikan akuntansi sebagai seni pencatatan, penggolongan, dan peringkasan transaksi dan kejadian yang bersifat keuangan dengan cara yang berdaya guna dan dalam bentuk satuan uang, dan penginterpretasian hasil proses tersebut. Secara sederhana, pengertian akuntansi syariah dapat dijelaskan melalui akar kata yang dimilikinya yaitu akuntansi dan syariah. Definisi bebas dari akuntansi adalah identifikasi transaksi yang kemudian diikuti dengan kegiatan pencatatan, penggolongan serta pengikhtisaran transaksi tersebut sehingga menghasilkan laporan keungan yang dapat digunakan untuk pengambilan keputusan. Definisi bebas dari syariah adalah aturan yang telah ditetapkan oleh Allah SWT untuk dipatuhi oleh manusia dalam menjalani segala aktivitas hidupnya didunia. Jadi, akuntansi syariah dapat diartikan sebagai proses akuntansi atas transaksi-transaksi yang sesuai dengan aturan Allah SWT (Nurhayati, 2011:2). Oleh karena itu, akuntansi syariah diperlukan untuk mendukung aktivitas ekonomi yang dilakukan sesuai syariah.

Perintah untuk melakukan pencatatan transaksi jual-beli ataupun transaksi muamalah lainnya terdapat dalam Al-Quran Surat Al-Baqarah 282. Allah SWT berfirman:

Yā 'ayyuhal-lażīna 'āmanū 'iżā tadāyantum bi dainin ilā 'ajalim musamman faktubūh

"Hai orang-orang yang beriman, apabila kamu bermu'amalah tidak secara tunai untuk waktu yang ditentukan, hendaklah kamu menuliskannya. dan hendaklah seorang penulis di antara kamu menuliskannya dengan benar. "(QS: 2:282)

\section{Murabahah}

Antonio (2007:101) berpendapat murabahah adalah jual beli barang pada harga asal dengan tambahan keuntungan yang disepakati, penjual harus memberi tahu harga produk yang ia beli dan menentukan suatu tingkat keuntungan sebagai tambahannya. Sedangkan Harahap, Wiroso dan Yusuf (2007:111) murabahah adalah akad jual beli barang dengan menyatakan harga perolehan dan keuntungan (margin) yang disepakati oleh penjual dan pembeli. Jadi dapat disimpulkan bahwa murabahah 
adalah transaksi jual beli barang, dimana penjual menegaskan harga perolehan dan keuntungan pada pembeli. Jenis-jenis jual beli murabahah menurut Harahap, Wiroso, dan Yusuf (dalam Jamaluddin, 2011):

1. Murabahah tanpa pesanan artinya ada yang beli atau tidak bank syariah menyediakan barang dan

2. Murabahah berdasarkan pesanan atau bisa disebut murabahah kepada pemesan pembelian artinya bank syariah baru melakukan transaksi jual beli apabila ada pesanan. Menurut antonio (2007:103) murabahah jenis ini biasa disebut murabahah kepada pemesan pembelian (KPP).

\section{PSAK 102 - Murabahah}

PSAK 102 - akuntansi murabahah telah disahkan oleh Dewan Standar Akuntansi Keuangan pada tanggal 27 Juni 2007.

Pernyataan ini tidak mencakup peraturan akuntansi atas obligasi syariah (sukuk) yang menggunakan akad murabahah.

Berdasarkan PSAK 102-Akuntansi Murabahah paragraf 18-30 pengakuan dan pengukuran akuntansi untuk penjual adalah sebagai berikut :

1. Pada saat perolehan, aset murabahah diakui sebagai persediaan sebesar biaya perolehan.

2. Pengukuran aset murabahah setelah perolehan adalah sebagai berikut:

a. Jika murabahah pesanan mengikat:

i. Dinilai sebesar biaya perolehan; dan

ii. Jika terjadi penurunan nilai aset karena usang, rusak, atau kondisi lainnya sebelum diserahkan kenasabah, penurunan nilai tersebut diakui sebagai beban dan mengurangi nilai aset.

b. Jika murabahah tanpa pesanan atau murabahah pesanan tidak mengikat:

i. Dinilai berdasarkan biaya perolehan atau nilai bersih yang dapat direalisasi, mana yang lebih rendah; dan

ii. Jika nilai bersih yang dapat direalisasi lebih rendah dari biaya perolehan, maka selisihnya diakui sebagai kerugian.

3. Diskon pembelian aset murabahah diakui sebagai berikut:

a. Jika terjadi sebelum akad murabahah maka sebagai pengurangan biaya perolehan aset murabahah;

b. Jika terjadi setelah akad murabahah dan sesuai akad yang disepakati maka bagian yang menjadi hak nasabah;

i. Dikembalikan kepada nasabah jika nasabah masih berada dalam proses penyeleseian kewajiban; atau

ii. Kewajiban kepada nasabah jika nasabah telah menyeleseikan kewajiban.

c. Jika terjadi setelah akad murabahah dan sesuai akad yang menjadi bagian hak lembaga keuangan syariah diakui sebagai tambahan keuntungan murabahah;

d. Jika terjadi setelah akad murabahah dan tidak diperjanjikan dalam akad diakui sebagai pendapatan operasional lain.

4. Kewajiban penjual kepada pembeli atas pengembalian diskon pembelian akan tereliminasi pada saat:

a. Dilakukan pembayaran kepada pembeli sebesar jumlah potongan setelah dikurangi dengan biaya pengembalian; atau

b. Dipindahkan sebagai dana kebajikan jika pembeli sudah tidak dapat dijangkau oleh penjual.

5. Pengakuan piutang 
a. Pada saat akad murabahah, piutang murabahah diakui sebesar biaya perolehan aset murabahah ditambah keuntungan yang disepakati.

b. Pada akhir periode laporan keuangan, piutang murabahah dinilai sebesar nilai bersih yang dapat direalisasi, yaitu saldo piutang dikurangi penyisihan kerugian piutang.

6. Pengakuan keuntungan

Keuntungan murabahah diakui:

a. Pada saat terjadinya akad murabahah jika dilakukan secara tunai atau secara tangguh sepanjang masa angsuran murabahah tidak melebihi satu periode laporan keuangan; atau

b. Selama periode akad secara proporsional, jika akad melampaui satu periode keuangan.

7. Potongan pelunasan piutang murabahah yang diberikan kepada pembeli yang melunasi secara tepat waktu atau lebih cepat dari waktu yang disepakati diakui dengan menggunakan salah satu metode berikut:

a. Jika diberikan pada saat penyeleseian, maka penjual mengurangi piutang murabahah dan keuntungan murabahah; atau

b. Jika diberikan setelah penyeleseian, maka penjual terlebih dahulu menerima pelunasan piutang murabahah dari pembeli, kemudian penjual membayar potongan pelunasan (muqasah) kepada pembeli dengan mengurangi keuntungan murabahah.

8. Potongan angsuran murabahah diakui sebagai berikut:

a. Jika disebabkan oleh pembeli yang membayar secara tepat waktu diakui sebagai pengurangan keuntungan murabahah;

b. Jika disebabkan oleh penurunan kemampuan pembayaran pembeli diakui sebagai beban.

9. Pengakuan denda

Denda dikenakan jika pembeli lalai dalam melakukan kewajibannya sesuai dengan akad, dan denda yang diterima diakui sebagai dana kebajikan.

10. Pengakuan dan pengukuran uang muka adalah sebagai berikut:

a. Uang muka diakui sebagai uang muka pembelian sebesar jumlah yang diterima;

b. Jika barang jadi di beli oleh pembeli,maka uang muka diakui sebagai pembayaran piutang (merupakan bagian pokok);

c. Jika barang batal di beli oleh pembeli,maka uang muka dikembalikan kepada pembeli setelah di perhitungkan dengan biaya-biaya yang telah dikeluarkan oleh penjual.

\section{Laporan Keuangan}

Laporan keuangan merupakan hasil akhir dari segala proses yang berkaitan dengan penyediaan dan penyampaian atas segala informasi transaksi keuangan kepada pihak yang bersangkutan dan membutuhkan laporan keuangan dengan maksud mencapai tujuan sebuah perusahaan atau organisasi.

Dari semua proses diatas harus tetap dilandasi dengan prinsip sebagai berikut:

a. Pengakuan

Menurut Yadiati (2007:63) pengakuan merupakan proses pencatatan formal atau mencatat item-item tertentu atau dengan kata lain, mencatat jumlah rupiah suatu item yang harus diungkapkan ke dalam laporan keuangan.

b. Pengukuran 
Pengukuran adalah proses penetapan jumlah uang untuk mengakui dan memasukkan setiap unsur laporan keuangan dalam neraca dan laporan laba rugi.

c. Pengungkapan

Pengungkapan merupakan suatu prinsip yang menyatakan bahwa praktik yang umum dilakukan dalam memutuskan informasi apa yang akan dilaporkan adalah menyediakan informasi yang mencukupi untuk mempengaruhi penilaian dan keputusan pemakai.

d. Penyajian

Penyajian merupakan proses menyajikan data akuntansi yang tercatat dalam rekening-rekening buku besar yang akan disajikan dalam bentuk laporan keuangan, yaitu neraca, laporan surplus-deficit (laporan kinerja keuangan) dan laporan arus kas.

\section{Proposisi}

Penelitian ini didasarkan atas proposisi, bahwa penerapan transaksi murabahah yang benar akan menimbulkan kesesuaian antara pengakuan, pengukuran, pencatatan, penyajian, pengungkapan dengan standar akuntansi syariah yaitu PSAK No. 102-akuntansi murabahah.

\section{KERANGKA BERFIKIR}




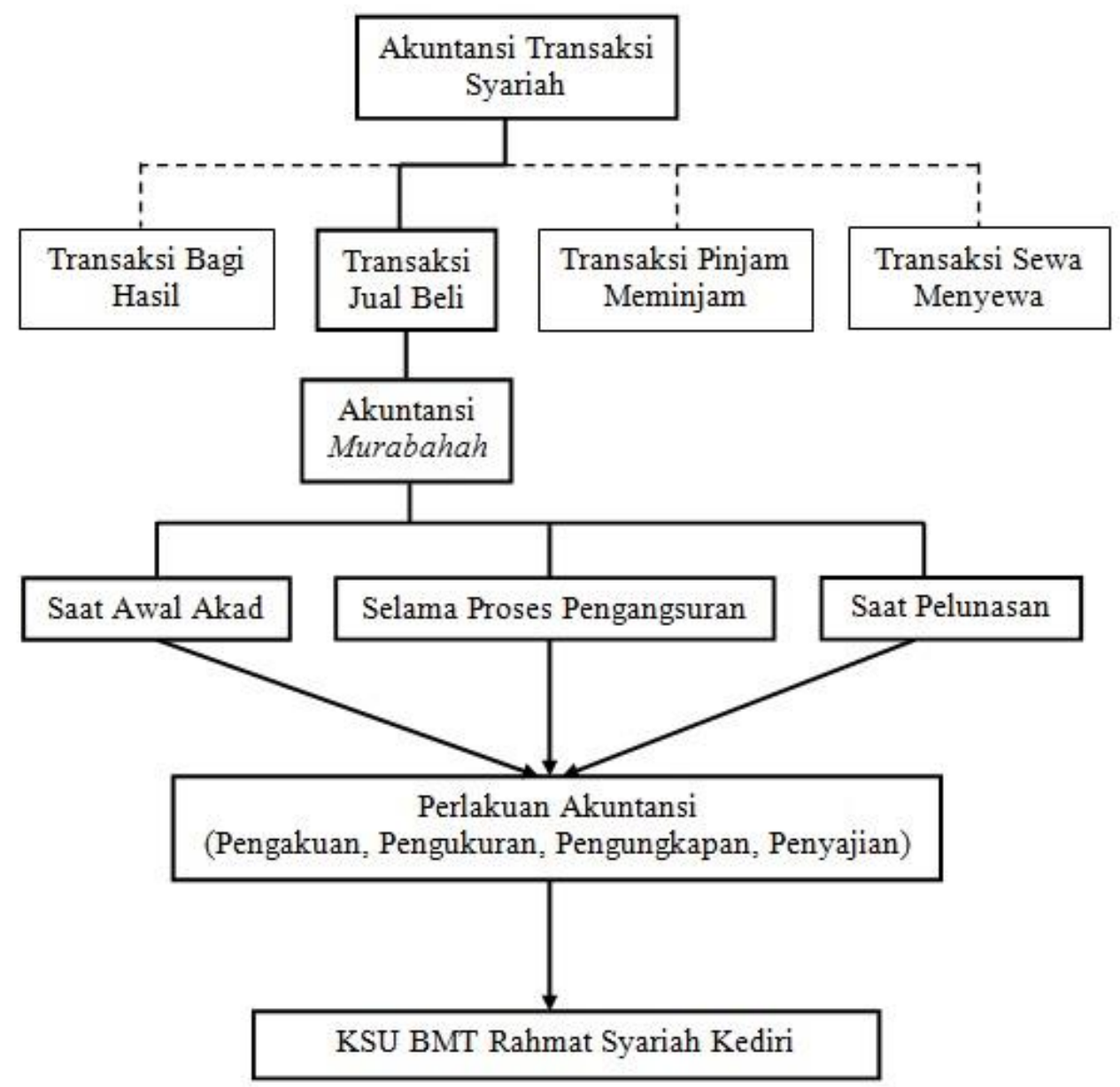

Sumber: Penulis

\section{Gambar 1. Kerangka Berfikir}

Kerangka berfikir tersebut menjelaskan alur dari penelitian ini. Dimana akuntansi transaksi syariah meliputi transaksi bagi hasil dalam bentuk mudharabah dan musyarakah, transaksi jual beli dalam bentuk piutang murabahah, salam, dan istishna, transaksi pinjam meminjam dalam bentuk piutang qardh dan transaksi sewa menyewa dalam bentuk ijarah. Akuntansi transaksi jual beli bentuk murabahah sebagai transaksi yang diteliti. Penelitian ini akan berfokus pada penerapan akuntansi murabahah yang meliputi pada saat awal akad, selama proses pengangsuran, dan saat pelunasan transaksi murabahah. Ketiga hal tersebut selanjutnya akan diteliti bagaimana perlakuan akuntansinya pada KSU BMT Rahmat Syariah Kediri dan apakah telah sesuai dengan PSAK No 102 - akuntansi transaksi murabahah.

\section{METODE PENELITIAN}

Metode penelitian yang digunakan adalah pendekatan kualitatif deskriptif dengan jenis penelitian studi kasus. Unit analisis dalam penelitian ini adalah perlakuan akuntansi murabahah yang diterapkan pada BMT Rahmat Syariah. Teknik analisis yang digunakan dalam penelitian ini adalah teknik analisis domain. Dari hasil penelitian dapat ditentukan tiga domain terkait akad murabahah yaitu saat awal akad, selama proses pengangsuran dan saat pelunasan.

\section{HASIL dan PEMBAHASAN}

BMT Rahmat Syariah berdiri pada tanggal 1 Agustus 2003 namun baru diresmikan operasionalnya pada tanggal 25 Agustus 2003 oleh KH. Imam Yahya Malik (pengasuh Pondok Pesantren Al-Ma'aruf Kedunglu Kediri). BMT ini berdiri 
setelah melihat kenyataan bahwa krisi ekonomi tiada henti dan tiada solusi; penduduk menjadi miskin, menganggur dan terputus hubungan kerjanya; terjadi jurang pemisah antara si kaya dan si miskin; pengusaha kecil haus modal sementara bank belum menjangkau; serta banyak bank konvensional berguguran sedangkan bank syariah belum ada di Kediri.

Produk-produk yang dikeluarkan oleh BMT Rahmat Syariah:

1. Produk Kepemilikan Saham

Investasi mulia dan terbuka bagi masyarakat umum, baik perorangan maupun kolektif (yayasan, kelompok, koperasi, dll) yang bermaksud ikut memiliki BMT Rahmat Syariah. Dengan membeli saham BMT minimal 2 (dua) lembar.

2. Produk Simpanan atau Tabungan

a. Tabungan Mudharabah/Simasis Biasa

Fasilitas tabungan bagi masyarakat baik perorangan maupun kolektif yang mendambakan kehidupan aman, nyaman, dan menjanjikan. Sesuai dengan namanya tabungan ini tidak dibatasi jumlahnya dan waktu pengambilannya.

b. Deposito Mudharabah/Simpanan Berjangka

Fasilitas tabungan bagi perorangan maupun kolektif yang ingin melakukan investasi mulia dalam jangka waktu tertentu. Dengan mendepositkan dana minimal 1 (satu) juta dalam waktu 3 bulan, 6 bulan, 12 bulan atau 24 bulan anda akan mendapat bagi hasil yang memuaskan.

c. Tabungan Sosial

Fasilitas tabungan khusus bagi mereka yang berniat membayar zakat, infaq, shadaqoh untuk kepentingan kemanusiaan tanpa mengurangi jumlah dana yang ditabung. Dengan menitipkan sejumlah dana berarti anda telah membantu orang lain yang kekurangan, karena dan akan disalurkan untuk pembiayaan qardhul hasan. Pihak penabung diberikan kesempatan untuk menunjuk orang-orang atau yayasan atau kelompok yang akan disantuni.

3. Produk Pembiayaan

a. Pembiayaan Mudharabah

Pembiayaan dengan akad sirkah/kerjasama antara BMT dengan anggota yang menjalankan usaha dengan modal seluruhnya berasal dari BMT. Dalam jangka waktu tertentu hasil keuntungan usaha akan dibagi sesuai kesepakatan.

b. Pembiayaan Musyarakah

Pembiayaan dengan akad sirkah/kerjasama antara BMT dengan anggota yang menjalankan usaha dengan modal yang tidak seluruhnya berasal dari BMT. Dalam jangka waktu tertentu hasil keuntungan usaha akan dibagi sesuai kesepakatan.

c. Pembiayaan Murabahah

Sistem pembiayaan dengan akad jual beli, dimana nasabah membutuhkan barang (alat untuk sarana usaha) dan BMT menyediakan barangnya. Kemudian nasabah membelinya di BMT dengan pembayaran dibelakang atau jatuh tempo. Besarnya harga dan lamanya pembayaran ditentukan berdasarkan kesepakatan kedua belah pihak.

d. Pembiayaan Bai' Bittaman Ajil

Sistem pembiayaan dengan akad jual beli, dimana nasabah membutuhkan barang (alat untuk sarana usaha) dan BMT menyediakan barangnya. Kemudian nasabah membelinya di BMT dengan pembayaran diangsur. Mengenai besarnya angsuran dan lamanya pembayaran ditentukan berdasarkan kesepakatan kedua belah pihak. 


\section{Program LAZis}

Sebagai lembaga Baitul Maal, BMT akan mengumpulkan zakat, infaq, shadaqah, hibah dan berbagai bentuk sumbangan lainnya, dari orang-orang yang peduli untuk disalurkan secara efektif dan efisien kepada kaum dhuafa. Bantuan ini akan disertai pembinaan dan bimbingan kearah pemberdayaan.

Dalam penyelesaian penelitian, penulis menggali informasi kepada informan yang berada di BMT Rahmat Syariah sebanyak dua informan:

Informan pertama, data yang digali didapatkan dari bapak Moh. Arif Hanafi sebagai manajer. Beliau juga merupakan salah satu pendiri BMT Rahmat Syariah. Sebagai lulusan teknik beliau cukup memahami pentingnya menggunakan sistem ekonomi syariah serta dapat memberikan gambaran secara umum alur dan proses akad murabahah yang berjalan di BMT Rahmat Syariah.

Informan kedua, data yang digali dari bu Eni Nurhayati sebagai kepala bagian pembukuan. Karena bagian pembukuan merupakan pihak yang paling mengetahui atas seluruh perlakuan akuntansi pada BMT Rahmat Syariah. Beliau menjelaskan bagaimana pengakuan, pengukuran, pengungkapan serta penyajian transaksi akad murabahah yang diterapkan oleh BMT Rahmat Syariah.

BMT Rahmat Syariah dalam menyalurkan dananya memiliki persyaratan, prosedur dan tatacara tersendiri tapi sesuai dengan mekanisme penyaluran dana pada umumnya. Dalam produk pembiayaan murabahah BMT Rahmat Syariah menyediakan produk pembiayaan dengan sistem wakalah murabahah. Dalam mengajukan pembiayaan murabahah kepada BMT Rahmat Syariah barang yang diajukan harus jelas dan halal. Pembiayaan murabahah dapat diajukan bila yang bersangkutan merupakan anggota BMT Rahmat Syariah, calon anggota BMT Rahmat Syariah atau anggota koperasi lain. Adapun persyaratan yang harus dipenuhi oleh mitra (nasabah) pemohon pembiayaan murabahah diantaranya fotocopy Kartu Tanda Penduduk (KTP), fotocopy Kartu Keluarga (KK), fotocopy jaminan (BPKB mobil/motor, Sertifikat Tanah), meembayar administrasi anggota.

Setelah syarat-syarat tersebut terpenuhi, pemohon mengisi formulir aplikasi permohonan pembiayaan, kemudian menyerahkan syarat-syarat tersebut dengan lengkap. Selanjutnya permohonan yang diajukan oleh mitra (nasabah) akan diserahkan ke bagian pembiayaan untuk disurvey kelayakannya. Setelah itu bagian pembiayaan melaporkan hasil analisis kelayakan kepada manajer. Persetujuan lolos tidaknya suatu pembiayaan ditentukan bersama oleh manajer dan bagian pembiayaan. Apabila pembiayaan yang diajukan oleh nasabah lebih dari 50 (lima puluh) juta maka harus meminta persetujuan kepada pengurus.

Sehubungan dengan bentuk transaksi murabahah yang diterapkan pada BMT Rahmat Syariah, berikut ini adalah contoh kasus pembiayaan murabahah atas nama bapak Moh. Alwan (kasus pertama) dan kasus pembiayaan murabahah atas nama bapak Adrian Susanto (kasus kedua).

Kasus pertama: Tanggal 13 November 2013 Bapak Moh. Alwan telah menandatangani akad pembiayaan murabahah untuk pembelian kelapa sawit. BMT Rahmat Syariah telah menyerahkan uang sebesar Rp 35.000.000,- (tiga puluh lima juta rupiah) kepada Bapak Alwan. Dan telah disepakati bahwa pembayaran dilakukan secara tangguh, yang akan dibayarkan setiap bulan selama lima (5) kali. Dengan jatuh tempo pada tanggal 13 April 2014. Margin yang disepakati adalah $12,5 \%$

Kasus kedua : Pada tanggal 22 Desember 2011 Bapak Adrian Susanto telah menandatangani akad pembiayaan murabahah untuk pembelian alat pertanian. BMT Rahmat Syariah telah menyerahkan uang sebesar Rp 6.000.000,- (enam juta rupiah) 
kepada Bapak Adrian. Dan telah disepakati bahwa pembayaran secara tangguh, yang akan dibayarkan setiap bulan selama enam belas (16) kali. Dengan jaminan berupa Bukti Kepemilikan Kendaraan Bermotor (BPKB). Jatuh tempo pada tanggal 22 April 2013 dan margin yang disepakati adalah $28 \%$.

Pada akhirnya terjadi keterlambatan pembayaran. Sudah dilakukan pendekatan kekeluargaan untuk mengetahui penyebab Bapak Adrian tidak dapat mengangsur sesuai jadwal dan dapat mengangsur kembali. Namun tidak terselesaikan sehingga Bapak Adrian harus dikenakan ta'zir sebesar 5\% dari pokok apabila mitra (nasabah) melakukan keterlambatan pembayaran angsuran. Mobil yang menjadi jaminanpun harus ditarik oleh BMT Rahmat Syariah. Mobil yang dijadikan jaminan dalam kondisi tidak layak jual, sehingga BMT Rahmat Syariah mengaku kesulitan dalam hal penjualan jaminan tersebut. Hasil penjualan mobil digunakan untuk menutup kekurangan angsuran ditambah dengan ta'zir. Berikut adalah perbandingan perlakuan akuntansi BMT Rahmat Syariah dengan PSAK 102 berdasarkan kasus bapak Alwan antara lain saat pembeliian barang yang diwakilkan (murabahah bil wakalah), saat akad murabahah disepakati, saat penerimaan angsuran jatuh tempo dari mitra (nasabah), saat pelunasan, sedangkan kasus Bapak Adrian hanya diambil perlakuan yang berhubungan dengan pembayaran angsuran sebagian saat jatuh tempo dan saat pelunasan setelah jatuh tempo yang terkena denda.

\section{Tabel 1. Perbandingan Perlakuan Akuntansi BMT Rahmat Syariah dengan PSAK 102}

\begin{tabular}{|c|c|c|c|}
\hline No. & $\begin{array}{c}\text { Jenis } \\
\text { Transaksi }\end{array}$ & $\begin{array}{c}\text { Jurnal BMT Rahmat } \\
\text { Syariah }\end{array}$ & Jurnal Berdasarkan PSAK 102 \\
\hline 1. & $\begin{array}{l}\text { Saat } \\
\text { pembeliaan } \\
\text { barang yang } \\
\text { diwakilkan } \\
\text { (murabahah bil } \\
\text { wakalah) }\end{array}$ & $\begin{array}{l}\text { BMT Rahmat Syariah tidak } \\
\text { melakukan pengakuan } \\
\text { apapun terkait pembelian } \\
\text { barang yang diwakilkan } \\
\text { pada mitra (nasabah). }\end{array}$ & $\begin{array}{l}\text { (Db) Piutang wakalah Rp } \\
35.000 .000 \\
\text { (Kr) Kas Rp } 35.000 .000 \\
\text { (Db) Persediaan murabahah Rp } \\
\text { 35.000.000 } \\
\text { (Kr) Piutang wakalah Rp } \\
\quad 35.000 .000\end{array}$ \\
\hline 2. & $\begin{array}{l}\text { Saat akad } \\
\text { murabahah } \\
\text { disepakati }\end{array}$ & $\begin{array}{l}\text { (Db) Kas Rp } 700.000 \\
\text { (Kr) Pendapatan } \\
\text { administrasi } \\
\text { pembiayaan Rp } \\
700.000\end{array}$ & $\begin{array}{l}\text { (Db) Piutang murabahah Rp } \\
\text { 39.375.000 } \\
\text { (Kr) Persediaan murabahah } \\
\text { Rp 35.000.000 } \\
\text { (Kr) Margin murabahah yg } \\
\text { ditangguhkan Rp 4.375.000 } \\
\text { (Db) Kas Rp 700.000 } \\
\text { (Kr) Pendapatan administrasi } \\
\text { Rp 700.000 }\end{array}$ \\
\hline 3. & $\begin{array}{l}\text { Saat } \\
\text { penerimaan } \\
\text { angsuran dari } \\
\text { mitra (nasabah) }\end{array}$ & $\begin{array}{l}\text { (Db) Kas Rp } 875.000 \\
\text { (Kr) Pendapatan bagi } \\
\text { hasil pembiayaan Rp } \\
875.000\end{array}$ & $\begin{array}{l}\text { (Db) Kas Rp } 7.875 .000 \\
\text { (Kr) Piutang murabahah Rp } \\
7.875 .000 \\
\text { (Db) Margin murabahah yg } \\
\text { ditangguhkan Rp } 875.000 \\
\text { (Kr) Pendapatan margin } \\
\quad \text { murabahah Rp } 875.000\end{array}$ \\
\hline 4. & Saat pelunasan & (Db) Kas Rp 35.875.000 & $(\mathrm{Db})(\mathrm{Db})$ Kas Rp 7.875 .000 \\
\hline
\end{tabular}




\begin{tabular}{|c|c|c|c|}
\hline No. & $\begin{array}{c}\text { Jenis } \\
\text { Transaksi }\end{array}$ & $\begin{array}{c}\text { Jurnal BMT Rahmat } \\
\text { Syariah }\end{array}$ & Jurnal Berdasarkan PSAK 102 \\
\hline \multirow{11}{*}{5.} & \multirow{11}{*}{$\begin{array}{l}\text { Saat } \\
\text { pembayaran } \\
\text { angsuran } \\
\text { sebagian saat } \\
\text { jatuh tempo }\end{array}$} & $\begin{array}{l}\text { (Kr) Pembiayaan } \\
\text { murabahah } \mathrm{Rp}\end{array}$ & $\begin{array}{l}\text { (Kr) Piutang murabahah Rp } \\
7.875 .000\end{array}$ \\
\hline & & 35.000 .000 & (Db) Margin murabahah yg \\
\hline & & (Kr) Pendapatan bagi & ditangguhkan $\mathrm{Rp} 875.000$ \\
\hline & & hasil pembiayaan Rp & (Kr) Pendapatan margin \\
\hline & & 875.000 & murabahah $\operatorname{Rp} 875.000$ \\
\hline & & (Db) Kas Rp 320.000 & (Db) Kas Rp 320.000 \\
\hline & & (Kr) Pembiayaan & (Db) Piutang murabahah jatuh \\
\hline & & murabahah Rp 215.000 & tempo Rp 160.000 \\
\hline & & $\begin{array}{l}\text { (Kr) Pendapatan bagi } \\
\text { hasil pembiavaan } \mathrm{Rp}\end{array}$ & (Kr) Piutang murabahah Rp \\
\hline & & 105.000 & $\begin{array}{l}\text { (Db) Margin murabahah yang } \\
\text { ditangguhkan Rp } 105.000\end{array}$ \\
\hline & & & $\begin{array}{l}\text { (Kr) Margin murabahah } \\
\text { jatuh tempo Rp } 105.000\end{array}$ \\
\hline \multirow[t]{5}{*}{6.} & Saat terjadi & & (Db) Piutang murabahah jatuh \\
\hline & keterlambatan & & tempo $\mathrm{Rp} 480.000$ \\
\hline & pembayaran & & (Kr) Piutang murabahah \\
\hline & & Tidak ada jurnal & $\begin{array}{l}\text { (Db) Margin murabahah jatuh } \\
\text { tempo Rp } 105.000\end{array}$ \\
\hline & & & $\begin{array}{l}\text { (Kr) Pendapatan margin } \\
\text { murabahah } \mathrm{Rp} 105.000\end{array}$ \\
\hline \multirow[t]{9}{*}{7.} & Saat pelunasan & (Db) Kas Rp 4.500.000 & (Db) Kas Rp 4.500.000 \\
\hline & setelah jatuh & (Kr) Pembiayaan & (Kr) Piutang murabahah \\
\hline & tempo dan & murabahah $\mathrm{Rp}$ & jatuh tempo Rp 4.500 .000 \\
\hline & denda & 3.535 .000 & (Db) Margin murabahah jatuh \\
\hline & & (Kr) Pendapatan bagi & tempo Rp945.000 \\
\hline & & hasil pembiayaan Rp & (Kr) Pendapatan margin \\
\hline & & 945.000 & murabahah $\mathrm{Rp} 945.000$ \\
\hline & & (Db) Kas Rp 1.000 .750 & (Db) Kas Rp 1.000.750 \\
\hline & & (Kr) ZIS Rp 1.000.750 & $\begin{array}{l}\text { (Kr) Rek. Dana kebajikan Rp } \\
1.000 .750\end{array}$ \\
\hline
\end{tabular}

Sumber : Data Olahan

Setelah diperbandingkan perlakuan akuntansi antara BMT Rahmat Syariah dengan PSAK 102 selanjutnya dianalisis menggunakan analisis domain, taksonomi, dan komponensial.

Tabel 2. Analisis Domain

\begin{tabular}{|c|c|c|c|c|c|}
\hline \multirow{2}{*}{ No } & \multirow{2}{*}{$\begin{array}{l}\text { Analisis } \\
\text { Domain }\end{array}$} & \multirow{2}{*}{$\begin{array}{c}\text { Analisis } \\
\text { Taksonomi }\end{array}$} & \multicolumn{2}{|c|}{ Analisis Komponensial } & \multirow{2}{*}{ Kesesuaian } \\
\hline & & & Implementasi & PSAK 102 & \\
\hline \multirow[t]{2}{*}{1} & $\begin{array}{l}\text { Saat } \\
\text { Awal } \\
\text { Akad }\end{array}$ & $\begin{array}{c}\text { Kepemilikan } \\
\text { Barang }\end{array}$ & $\begin{array}{c}\text { BMT Rahmat } \\
\text { Syariah tidak } \\
\text { memiliki persediaan } \\
\text { barang murabahah. }\end{array}$ & $\begin{array}{l}\text { Pada saat perolehan, } \\
\text { aset murabahah diakui } \\
\text { sebagai persediaan } \\
\text { sebesar biaya } \\
\text { perolehan. } \\
\text { (paragraf 18) }\end{array}$ & $\begin{array}{l}\text { Pengakuan, } \\
\text { pengukuran, } \\
\text { penyajian, dan } \\
\text { pengungkapan } \\
\text { tidak sesuai } \\
\text { PSAK } 102\end{array}$ \\
\hline & & $\begin{array}{l}\text { Saat akad } \\
\text { disepakati }\end{array}$ & $\begin{array}{c}\text { Piutang murabahah } \\
\text { dicatat sebesar } \\
\text { pembiayaan yang } \\
\text { diajukan. }\end{array}$ & $\begin{array}{l}\text { Pada saat akad } \\
\text { murabahah, piutang } \\
\text { murabahah diakui } \\
\text { sebesar nilai perolehan }\end{array}$ & $\begin{array}{l}\text { Pengakuan, } \\
\text { pengukuran, } \\
\text { penyajian, dan } \\
\text { pengungkapan }\end{array}$ \\
\hline
\end{tabular}




\begin{tabular}{|c|c|c|c|c|c|}
\hline & & & & $\begin{array}{l}\text { ditambah keuntungan } \\
\text { yang disepakati. } \\
\text { (paragraf 22) }\end{array}$ & $\begin{array}{l}\text { tidak sesuai } \\
\text { PSAK } 102\end{array}$ \\
\hline \multirow[t]{2}{*}{2} & $\begin{array}{l}\text { Selama } \\
\text { Proses } \\
\text { Pengang } \\
\text { suran }\end{array}$ & $\begin{array}{l}\text { Keuntungan } \\
\text { murabahah }\end{array}$ & $\begin{array}{c}\text { Keuntungan diakui } \\
\text { proporsional dengan } \\
\text { ketentuan margin } \\
\text { sesuai kesepakatan } \\
\text { diawal akad. }\end{array}$ & $\begin{array}{l}\text { Keuntungan diakui } \\
\text { proporsional dengan } \\
\text { besaran kas yang } \\
\text { berhasil ditagih dari } \\
\text { piutang murabahah. } \\
\text { (paragraf } 23 \mathrm{~b} \text { - ii) }\end{array}$ & $\begin{array}{c}\text { Pengukuran } \\
\text { keuntungan } \\
\text { sudah sesuai } \\
\text { PSAK 102, } \\
\text { namun dalam } \\
\text { pengakuan, } \\
\text { penyajian, dan } \\
\text { pengungkapan } \\
\text { tidak sesuai } \\
\text { PSAK } 102\end{array}$ \\
\hline & & Denda & $\begin{array}{c}\text { Denda dibebankan } \\
\text { kepada mitra } \\
\text { (nasabah) apabila } \\
\text { angsuran lewat lima } \\
\text { (5) hari, sebesar 5\% } \\
\text { dari sisa pembiayaan } \\
\text { yang belum dibayar } \\
\text { untuk disalurkan ke } \\
\text { Baitul Maal bagi } \\
\text { kepentingan kaum } \\
\text { Dhuafa. }\end{array}$ & $\begin{array}{c}\text { Denda dikenakan jika } \\
\text { pembeli lalai dalam } \\
\text { melakukan } \\
\text { kewajibannya sesuai } \\
\text { dengan akad, dan } \\
\text { denda yang diterima } \\
\text { diakui sebagai bagian } \\
\text { dana kebajikan. } \\
\text { (paragraf 29) }\end{array}$ & $\begin{array}{c}\text { Pengakuan, } \\
\text { pengukuran, } \\
\text { dan } \\
\text { pengungkapan } \\
\text { sudah sesuai } \\
\text { PSAK 102. } \\
\text { Namun } \\
\text { penyajian } \\
\text { tidak sesuai } \\
\text { PSAK 102 }\end{array}$ \\
\hline 3 & $\begin{array}{l}\text { Saat } \\
\text { Pelunas } \\
\text { an }\end{array}$ & $\begin{array}{c}\text { Akhir } \\
\text { periode akad }\end{array}$ & $\begin{array}{c}\text { Piutang murabahah } \\
\text { dicatat sebesar nilai } \\
\text { pembiayaan yang } \\
\text { dilunasi. }\end{array}$ & $\begin{array}{c}\text { Piutang murabahah } \\
\text { dinilai sebesar nilai } \\
\text { bersih yang dapat } \\
\text { direalisasi, yaitu saldo } \\
\text { piutang dikurangi } \\
\text { penyisihan kerugian } \\
\text { piutang. } \\
\text { (paragraf 22) }\end{array}$ & $\begin{array}{c}\text { Pengukuran } \\
\text { telah sesuai } \\
\text { PSAK } 102 . \\
\text { Pengakuan, } \\
\text { penyajian, dan } \\
\text { pengungkapan } \\
\text { tidak sesuai } \\
\text { PSAK } 102\end{array}$ \\
\hline
\end{tabular}

Sumber : Data Olahan 
BMT Rahmat Syariah dalam pencatatan transaksi yang dilakukan menggunakan dasar cash basis sehingga setiap transaksi pencatatan yang dilakukan selalu berhubungan dengan kas. Hal ini menyebabkan tidak tercatatnya margin (keuntungan) murabahah diawal akad, karena pencatatan margin murabahah pada awal akad yang sesuai dengan PSAK 102 menggunakan dasar acrual basis. Karena menggunakan dasar cash basis sehingga mempengaruhi perlakuan pada beberapa transaksi diantaranya:

a. Perlakuan akuntansi atas kepemilikan barang

BMT Rahmat Syariah menerapkan murabahah bil wakalah dimana pembelian barang diwakilkan kepada mitra (nasabah). BMT Rahmat Syariah memberikan sejumlah uang sesuai dengan yang tertera pada perjanjian akad pembiayaan. Sesuai dengan PSAK 102, seharusnya ketika penyerahan uang pembelian barang BMT Rahmat Syariah melakukan pencatatan atas transaksi murabahah bil wakalah tersebut dan ketika barang yang dimaksud oleh mitra (nasabah) sudah terbeli seharusnya terjadi pengakuan persediaan barang yang diakui sebesar biaya perolehan barang tersebut. Namun tidak terjadi pencatatan dan pengakuan terkait pembelian barang secara wakalah tidak pula diakui adanya persediaan aset murabahah. Ketika akad disepakati, BMT Rahmat Syariah baru melakukan pencatatan terkait pembiayaan yang diajukan oleh mitra (nasabah). Pencatatan tersebut berhubungan dengan pengakuan piutang murabahah dan biaya administrasi. BMT Rahmat Syariah mengakui piutang murabahah sebesar pembiayaan yang diajukan oleh mitra (nasabah) tanpa mengakui keuntungan (margin) yang telah disepakati oleh kedua belah pihak. Margin yang disepakati hanya tercantum pada kontrak akad pembiayaan dan buku piutang, namun tidak tercatat pada jurnal.

b. Perlakuan akuntansi saat akad disepakati

Bila disesuaikan dengan PSAK 102, BMT Rahmat Syariah seharusnya mengakui piutang murabahah sebesar nilai perolehan ditambah keuntungan yang disepakati. PSAK 102 paragraf 22 juga mengatur bahwa "Pada saat akad murabahah, piutang murabahah diakui sebesar biaya perolehan aset murabahah ditambah keuntungan yang disepakati". Pencatatan yang dilakukan oleh BMT Rahmat Syariah pun kurang sesuai dalam hal penamaan akun karena akun yang sesuai dengan PSAK 102 adalah akun pembiayaan murabahah namun BMT Rahmat Syariah memberi akun tersebut dengan nama pembiayaan murabahah. Perlakuan akuntansi tersebut tidak mengakui adanya keuntungan (margin) murabahah diawal akad. Sehingga jumlah piutang yang harus ditanggung oleh mitra (nasabah) tidak diungkapkan diawal akad. Ketidakjelasan berapa jumlah piutang yang ditanggung oleh mitra (nasabah) ini mencerminkan ketidakterbukaan entitas yang bersangkutan. Karena awal akad sangat menentukan besarnya jumlah piutang yang harus ditagihkan kepada mitra (nasabah), apabila tidak diungkapkan diawal bisa terdapat kerancuan dalam pembacaan laporan keuangan tersebut. Model pengungakapan seperti ini sama dengan model pengungkapan yang dilakuakan oleh LKS yang tidak menggunakan prinsip-prinsip syariah dalam anggaran dasarnya.

c. Perlakuan akuntansi atas keuntungan murabahah

Keuntungan yang diterapkan oleh BMT Rahmat Syariah menggunakan model penerapan keuntungan proporsional dimana tiap terjadi penagihan piutang diakui sebagai pendapatan. Dan jumlahnya merupakan perbandingan antara margin dan pembiayaan yang diajukan. PSAK 102 paragraf 24 mengatur bahwa "Pengakuan keuntungan, dalam paragraf 23 (b) (ii), dilakukan secara proporsional atas jumlah piutang yang berhasil ditagih dengan mengalikan persentase keuntungan terhadap jumlah piutang yang berhasil ditagih. Persentase keuntungan dihitung dengan perbandingan antara margin dan biaya perolehan aset murabahah". Sesungguhnya yang dimaksudkan oleh BMT Rahmat Syariah sudah mendekati aturan pada PSAK 102. Pencatatan yang dilakukan BMT 
Rahmat Syariah ini terlalu sederhana, dalam pengungkapan keuntungan tidak mengikuti standar PSAK 102. Hal tersebut terjadi karena BMT Rahmat Syariah menerapkan model pengangsuran pembayaran margin terlebih dahulu pokok belakangan. Sehingga tiap kali mitra (nasabah) melakukan pengangsuran, tidak tercatat pokok piutang yang telah dibayarkan oleh mitra.

d. Perlakuan akuntansi atas denda

BMT Rahmat Syariah membebankan denda (ta'zir) kepada mitra bila tanggal pengangsuran yang harusnya dilakukan oleh mitra (nasabah) lewat lima (5) hari dari waktu yang ditetapkan. Denda yang diterapkan kepada mitra sebesar 5\% dari nilai pokok yang belum dibayarkan. Denda yang diterima akan disalurkan ke Baitul Maal untuk kepentingan kaum dhuafa. Dalam PSAK 102 paragraf 29 juga diatur mengenai denda. "Denda dikenakan jika pembeli lalai dalam melakukan kewajibannya sesuai dengan akad, dan denda yang diterima diakui sebagai bagian dana kebajikan".

e. Perlakuan akuntansi pada akhir periode akad

Pada akhir periode akad piutang murabahah dicatat sebesar nilai pembiayaan yang dilunasi oleh mitra (nasabah). Pencatatan seperti ini memiliki maksud yang sama dengan PSAK 102 paragraf 22 yang menyatakan bahwa, "Piutang murabahah dinilai sebesar nilai bersih yang dapat direalisasi, yaitu saldo piutang dikurangi penyisihan kerugian piutang".

\section{SIMPULAN DAN SARAN \\ Simpulan}

Berdasarkan analisa hasil penelitian yang dilakukan pada perlakuan akuntansi yang diterapkan BMT Rahmat Syariah terhadap pembiayaan murabahah dari tahap saat awal akad, selama proses mengangsur hingga saat akhir akad dapat disimpulkan bahwa:

a. Dalam hal pengakuan, pengukuran, penyajian, dan pengungkapan terhadap transaksi awal akad tidak sesuai dengan PSAK 102

b. Selama proses akad, dalam hal pengukuran keuntungan murabahah telah sesuai dengan PSAK 102, namun dalam hal pengakuan, penyajian, dan pengungkapan tidak sesuai dengan PSAK 102. Sedangkan dalam pengakuan, pengukuran, dan pengungkapan denda (ta'zir) sudah sesuai dengan PSAK 102 hanya penyajiannya saja yang tidak sesuai dengan PSAK 102.

c. Pada saat pelunasan pengukuran telah sesuai dengan PSAK 102, namun pengakuan, penyajian, dan pengungkapan tidak sesuai dengan PSAK 102

\section{Saran}

Adapun saran dari penulis adalah :

a. Untuk BMT Rahmat Syariah:

BMT Rahmat Syariah diharapkan dapat menjalankan kegiatan pencatatan dan penyusunan laporan keuangan sesuai dengan standar yang berlaku PSAK Syariah demi menjaga rasa kepercayaan terhapap mitra (nasabah).

b. Untuk Pemerintah:

Diharapkan melalui Dinas Koperasi pemerintah dapat memberikan pembinaan dan pendampingan pada BMT atau yang lebih dikenal dengan Koperasi Jasa Keuangan Syariah (KJKS) agar pelaporan keuangan pada BMT/KJKS sesuai dengan PSAK terutama PSAK Syariah dalam rangka menjaga kepatuhan terhadap aturan yang berlaku secara umum. 
c. Untuk Penelitian Selanjutnya:

Penelitian selanjutnya diharapkan lebih terfokus pada akad yang ditransaksikan dan standar acuan yang dipakai agar perlakuan akuntansi kedepannya lebih bisa menggambarkan substansi yang terjadi sesuai dengan akad yang digunakan. 


\section{DAFTAR PUSTAKA}

Antonio, Muhammad Syafi'i. 2007. Bank Syariah: Dari Teori Ke Praktik. Jakarta: Gema Insani.

Arikunto, S. 1998. Prosedur Penelitian Suatu Pendekatan Praktek. Jakarta: PT. Rineka Cipta.

Buchori, Nur S. 2009. Koperasi Syariah. Sidoarjo: Masmedia Buana Pustaka.

Harahap, Sofyan, Wiroso, \& Yusuf, Muhammad. 2010. Akuntansi Perbankan Syariah (edisi 4). Versi e-book. Jakarta: Penerbit LPFE Usakti.

Hosen, Muhammad Nadratuzzaman, dkk. 2008. Lembaga Bisnis Syariah. Versi e-book. Jakarta: Pusat Komunikasi Ekonomi Syariah.

Huda dan Heykal, 2010. "Lembaga Keuangan Islam: Tinjauan Teoritis dan Praktis." Jakarta: Kencana Predana Media Group.

Ikatan Akuntan Indonesia. 2009. Standar Akuntansi Keuangan PER 1 Juli 2009 - PSAK 102. Jakarta: Salemba Empat.

Khadifya S., Aishanafi. 2014. Perlakuan Akuntansi Akad Musyarakah Mutanaqisah (Studi Kasus: KPR iB Pada Bank Muamalat Cabang Darmo Surabaya). Skripsi tidak diterbitkan. Surabaya Fakultas Ekonomi dan Bisnis Universitas Airlangga.

Masita, dkk. 2011. Analisis Penerapan Pernyataan Standar Akuntansi Keuangan (PSAK) Nomor 102 (Studi Kasus Pada Pegadaian Syariah Cabang Gunung Sari Balikpapan). Jurnal Penelitian Universitas Mulawarman.

Moleong, Lexy, 2002. Metodologi Penelitian Kualitatif. Bandung: PT. Remaja Rosdakarya.

Nabila. 2011. Perlakuan Akuntansi Terhadap Pembiayaan Murabahah Pada Bank Syariah Berdasarkan PSAK No. 102 Tentang Akuntansi Murabahah (Studi Kasus Pada Bank BRI Syariah Sidoarjo). Rangkuman Skripsi UPN "Veteran", Jawa Timur.

PINBUK. Tanpa Tahun. Peraturan Dasar dan Contoh AD ART BMT. Jakarta: wasantara net. id.

PINBUK. 1998. Pedoman Cara Pembentukkan BMT. Jakarta: PINBUK.

Setia Ningsih, Ita Yuliana. 2011. Perlakuan Akuntansi Murabahah Berdasarkan PSAK 102 Pada BMT Al-Fath. Skripsi Fakultas Syariah dan Hukum Universitas Negeri Syarif Hidayatullah.

Soemitra, Andri, 2009. "Bank dan Lembaga Keuangan Syariah” edisi pertama cetakan kedua. Jakarta: Kencana Predana Media Group.

Sudarsono, Heri. 2008. Bank dan Lembaga Keuangan Syariah Edisi Ketiga. Cetakan Pertama. Yogyakarta: Ekonisia.

Sugiyono. 2010. Metode Penelitian Pendidikan. Bandung: Alfabeta.

Suhendi, Hendi. 2009. Strategi Optimalisasi Peran BMT sebagai Penggerak Sektor Usaha Mikro. www.fe.unpad.ac.id (diakses pada 21 Oktober 2013 pukul:16.25).

Taufiqi, Nailit. 2011. Analisis Perlakuan Akuntansi Atas Kesesuaian Penerapan Prinsip Jual Beli Pada Transaksi Murabahah Di PT. BPR Syariah Jabal Nur Berdasarkan PSAK 102. Rangkuman Skripsi STIE Perbanas, Surabaya.

Warren, Reeve Fess. 2005. Pengantar Akuntansi I edisi 21. Jakarta: Salemba Empat.

Wiroso. 2011. Akuntansi Transaksi Syariah. Jakarta: Ikatan Akuntan Indonesia.

Yaya, Rizal, dkk. 2009. Akutansi Perbankan Syariah; Teori dan Praktik Kontemporer. Jakarta: Salemba Empat.

Yin, Robert K. 2012. Studi Kasus Desain dan Metode. Jakarta. PT. Raja Grafindo Persada. 